\title{
Molecular Genetics of Palmitoyl-Protein Thioesterase Deficiency in the U.S.
}

\author{
Amit K. Das, ${ }^{\star}$ Carlos H.R. Becerra, ${ }^{\star}$ Won Yi, ${ }^{\star}$ Jui-Yun Lu, ${ }^{*}$ Aristotle N. Siakotos, ${ }^{\ddagger}$ Krystyna E. Wisniewski, $\$$ \\ and Sandra L. Hofmann* \\ *Department of Internal Medicine and the Hamon Center for Therapeutic Oncology Research, University of Texas Southwestern Medical \\ Center, Dallas, Texas 75235; ${ }^{\ddagger}$ Department of Pathology, Indiana University School of Medicine, Indianapolis, Indiana 46202; ${ }^{\S}$ Department \\ of Pathological Neurobiology, New York State Institute for Basic Research in Developmental Disabilities, Staten Island, New York 10314;

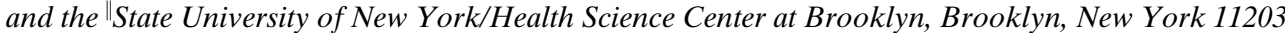

\section{Abstract}

Mutations in a newly described lysosomal enzyme, palmitoyl-protein thioesterase (PPT), were recently shown to be responsible for an autosomal recessive neurological disorder prevalent in Finland, infantile neuronal ceroid lipofuscinosis. The disease results in blindness, motor and cognitive deterioration, and seizures. Characteristic inclusion bodies (granular osmiophilic deposits [GROD]) are found in the brain and other tissues. The vast majority of Finnish cases are homozygous for a missense mutation (R122W) that severely affects PPT enzyme activity, and the clinical course in Finnish children is uniformly rapidly progressive and fatal.

To define the clinical, biochemical, and molecular genetic characteristics of subjects with PPT deficiency in a broader population, we collected blood samples from U.S. and Canadian subjects representing 32 unrelated families with neuronal ceroid lipofuscinosis who had GROD documented morphologically. We measured PPT activity and screened the coding region of the PPT gene for mutations. In 29 of the families, PPT deficiency was found to be responsible for the neurodegenerative disorder, and mutations were identified in 57 out of $58 \mathrm{PPT}$ alleles. One nonsense mutation ( $\mathrm{R} 151 \mathrm{X})$ accounted for $40 \%$ of the alleles and was associated with severe disease in the homozygous state. A second mutation (T75P) accounted for $13 \%$ of the alleles and was associated with a late onset and protracted clinical course. A total of 19 different mutations were found, resulting in a broader spectrum of clinical presentations than previously seen in the Finnish population. Symptoms first appeared at ages ranging from 3 mo to $9 \mathrm{yr}$, and about half of the subjects have survived into the second or even third decades of life. (J. Clin. Invest. 1998. 102:361-370.) Key

Address correspondence to Sandra L. Hofmann, Hamon Center for Therapeutic Oncology Research, University of Texas Southwestern Medical Center, 5323 Harry Hines Boulevard, Dallas, TX 752358593. Phone: 214-648-4911; FAX: 214-648-4940; E-mail: hofmann@ simmons.swmed.edu

C.H.R. Becerra's current address is Cra. 98 \#18-49, Fundacion Valle del Lili, Cali, Colombia.

Received for publication 15 February 1998 and accepted in revised form 30 April 1998.

J. Clin. Invest.

(C) The American Society for Clinical Investigation, Inc. 0021-9738/98/07/0361/10 \$2.00

Volume 102, Number 2, July 1998, 361-370

http://www.jci.org words: lysosomal storage disorders • thiolester hydrolases • neuronal ceroid lipofuscinosis - metabolic brain diseases • molecular genetics

\section{Introduction}

The neuronal ceroid lipofuscinoses $(\mathrm{NCLs})^{1}$ are a group of progressive hereditary neurodegenerative disorders of children that are distinguished from other neurodegenerative diseases by the accumulation of autofluorescent material ("aging pigment") in brain and other tissues (reviewed in reference 1). Distinct subgroups of NCL have been recognized that differ in the age of onset of symptoms and the appearance of the storage material by electron microscopy. Three major groups, infantile (INCL), classical late infantile (LINCL), and juvenile (JNCL) (characterized by granular osmiophilic deposits [GROD], curvilinear cellular inclusions, or fingerprint inclusions, respectively) are well defined and are now known to be caused by autosomal recessive mutations in the $C L N 1(2,3)$, CLN2 $(4,5)$, and CLN3 genes (6). (Fig. 1 illustrates the electron microscopic findings characteristic of these common NCL types). CLN4 refers to a rare adult NCL (Kuf's disease [7]) that has not been mapped to a genetic locus. A variant Finnish late infantile form is caused by a defect in a putative mapped CLN5 gene (8), and other atypical forms have been described (9). In the U.S. population, infantile, late infantile, juvenile, and adult NCL comprise $11.3 \%, 36.3 \%, 51.1 \%$, and $1.3 \%$ of cases with NCL, respectively (10).

Mutations in a lysosomal enzyme, palmitoyl-protein thioesterase (PPT), have been shown to cause INCL in Finland, where the disease is prevalent, as well as in two Northern European subjects with a similar clinical presentation (2). PPT functions in the removal of fatty acids from modified cysteine residues in proteins undergoing degradation in the lysosome (11), and cysteine-containing fatty acyl thioesters accumulate in cells derived from INCL subjects, leading to neurodegeneration by an unknown mechanism (12). In Finland, a single missense mutation (A364T, R122W) in the PPT gene is causative, the carrier frequency for the defective allele is 1 in 70 , and the mutation is associated with a complete loss of PPT function (2). The clinical disorder in Finland is remarkably homogeneous. Affected Finnish infants develop normally until the age of 6-24 mo, when visual failure, speech and motor deterioration, and seizures appear. Most subjects have no higher corti-

1. Abbreviations used in this paper: EEG, electroencephalogram; GROD, granular osmiophilic deposits; INCL, infantile neuronal ceroid lipofuscinosis; JNCL, juvenile neuronal ceroid lipofuscinosis; LINCL, classical late infantile neuronal ceroid lipofuscinosis; NCL, neuronal ceroid lipofuscinosis; PPT, palmitoyl-protein thioesterase; SSCP, single-strand conformational polymorphism. 

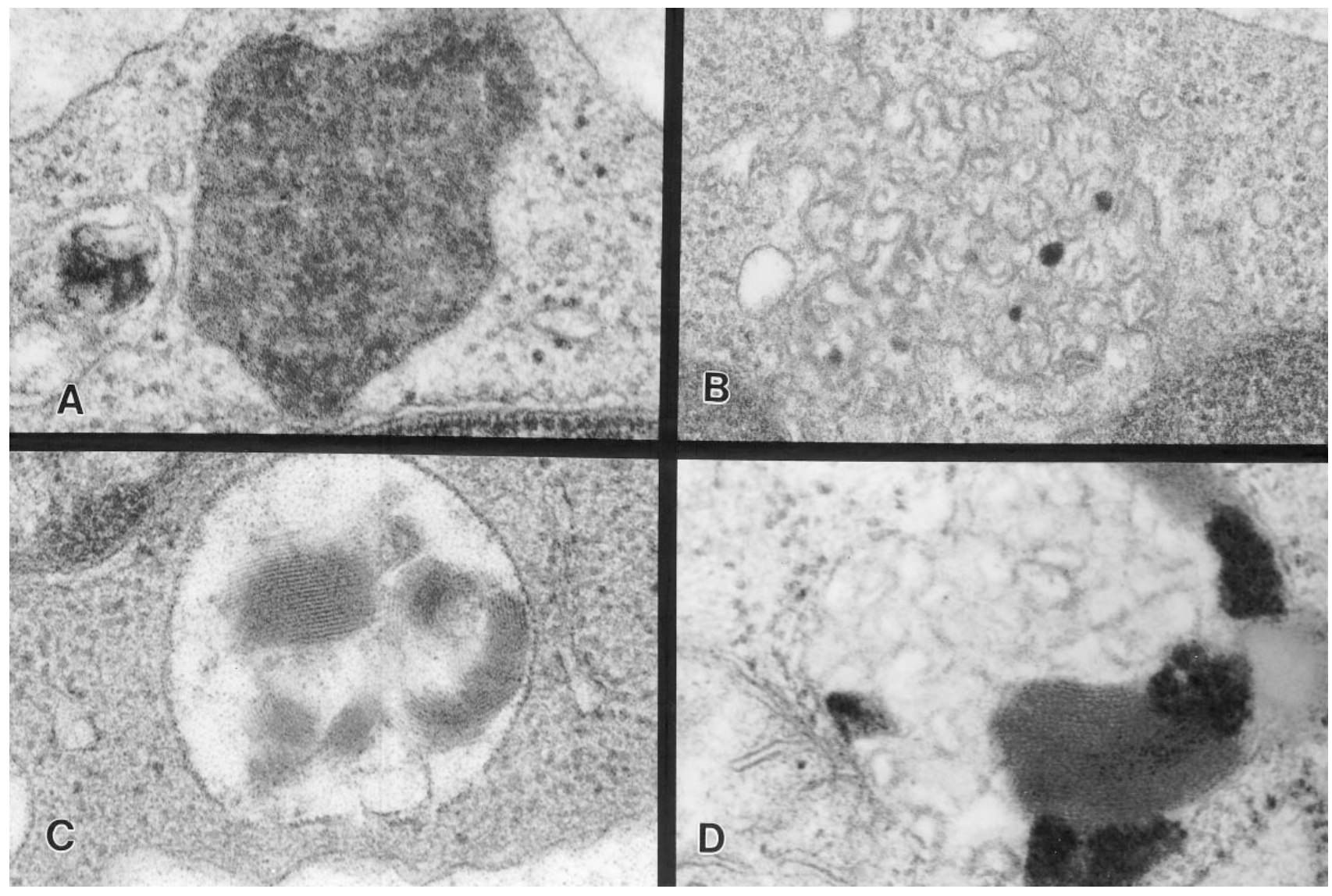

Figure 1. Lysosomal storage material in buffy coat (leukocyte) preparations from subjects with various types of NCL as seen by electron microscopy. ( $A)$ GRODs in an INCL (CLN1-/-) subject $(71,000 \times) ;(B)$ Curvilinear inclusions in a classical LINCL (CLN2-/-) subject (68,500×); $(C)$ Fingerprint profiles in a typical JNCL $(C L N 3-/-)$ subject $(64,000 \times) ;(D)$ Mixed granular, curvilinear, and fingerprint inclusions in a juvenile-onset PPT-deficient NCL subject $(C L N 1-/-)(108,000 \times)$.

cal activity demonstrable by an electroencephalogram (EEG) by the age of three (13).

Two other major forms of NCL, LINCL $(14,15)$ and JNCL (16), have been well described. Classical LINCL subjects present between the ages of 2 and $4 \mathrm{yr}$ with cognitive problems and developmental delay. These individuals have inclusion bodies that differ from those seen in the infantile type-the inclusions are in the form of curvilinear profiles, rather than GROD. Recently, defects in a lysosomal protease mapping to the $C L N 2$ locus have been demonstrated in these patients (5). JNCL subjects typically present between the ages of 4 and $7 \mathrm{yr}$ with visual failure, followed by a slow cognitive decline. The JNCL cases typically show "fingerprint" inclusions by electron microscopy and have defects in the CLN3 gene (6). The function of the CLN3 protein is unknown.

Recent evidence suggests that certain mutations in the PPT gene may produce a less severe form of NCL when compared to classical INCL. We recently identified three families who had been classifed as having LINCL but who had GROD histology. All three were deficient in PPT enzyme activity (17). In addition, $10 \mathrm{JNCL}$ families with GROD, most of whom were of Scottish ancestry, were recently shown to have mutations in the PPT gene (18).

To probe the spectrum of molecular defects in PPT and the relationship between these defects and the clinical presenta- tions of the disease, we obtained blood samples from 32 subjects in the Batten Disease Registry at the Institute for Basic Research (Staten Island, NY), who carried the diagnosis of NCL and who had electron microscopy of leukocytes or skin/ mucosa showing predominantly GROD histology. We also examined 16 classical LINCL subjects, and 12 cases referred to us with a clinical suspicion of INCL without a firm histologic diagnosis. We describe 19 different mutations in the PPT gene, and show that one nonsense mutation accounts for $40 \%$ of the alleles. Individuals homozygous for the common mutation have classic infantile NCL. The remaining majority of subjects with PPT deficiency are remarkably heterogeneous with respect to age of onset and pace of progression.

\section{Methods}

Subjects. 32 unrelated subjects with neurological deterioration and GROD (on electron microscopic examination of leukocytes or skin or mucosal biopsies) were entered into the study (Tables I and II). The histology was classified as either GROD only ( 23 subjects, Table I, line 1) or GROD mixed with curvilinear or fingerprint profiles (9 subjects, Table I, line 2). In addition, a further 16 unrelated subjects with classical LINCL, and 12 subjects with neurological disorders suggestive of INCL, but with nondiagnostic or normal histopathology were entered (Table I, lines 3 and 4) to serve as controls. All but four 
Table I. Electron Microscopy Findings in Study Subjects

\begin{tabular}{|c|c|c|c|c|c|c|c|c|}
\hline \multirow[b]{2}{*}{ EM results } & \multicolumn{2}{|c|}{ Infantile } & \multicolumn{2}{|c|}{ Late infantile } & \multicolumn{2}{|c|}{ Juvenile } & \multicolumn{2}{|c|}{ Overall } \\
\hline & Total & PPT-deficient & Total & PPT-deficient & Total & PPT-deficient & Total & PPT-deficient \\
\hline GROD & 14 & $14(100 \%)$ & 4 & $4(100 \%)$ & 5 & $5(100 \%)$ & 23 & $23(100 \%)$ \\
\hline GROD (mixed) & - & - & 1 & $1(100 \%)$ & 8 & $5(62 \%)$ & 9 & $6(67 \%)$ \\
\hline Curvilinear & - & - & 16 & $0(0 \%)$ & - & - & 16 & $0(0 \%)$ \\
\hline Nondiagnostic & 12 & $0(0 \%)$ & - & - & - & - & 12 & $0(0 \%)$ \\
\hline
\end{tabular}

subjects were registered with the Batten Disease Registry at the Institute for Basic Research (K. Wisniewski, Director) and the pathology in all of the registered cases was reviewed by one of us (K. Wisniewski). Clinical data were obtained from medical record review and interviews with physicians and parents. Two families (Nos. 28 and 29, Table I) have been reported in detail elsewhere (18) and are presented here for comparison only. Three clinical case histories representative of the infantile, late infantile, and juvenile presentations are given below.

Subject 9, a patient of Robert Steiner and Richard Weleber of the Oregon Health Sciences University in Portland, developed normally to the age of $12 \mathrm{mo}$, when the mother noted a regression in speech and motor function. The head circumference increased only $0.5 \mathrm{~cm}$ between 10 and 23 mo. Visual difficulties were noted at 14 mo and the patient was near blind at $20 \mathrm{mo}$. An MRI at 16 mo showed delayed myelination. An EEG was normal at 19 mo but she had generalized seizures at age $23 \mathrm{mo}$. An electroretinogram was abnormal and a conjunctival biopsy showed GROD in endothelial cells with occasional lamellar deposits but without curvilinear or fingerprint profiles.

Subject 19, a patient of Mark Laney of Fort Worth, Texas, was first referred to a child neurologist at the age of $3.5 \mathrm{yr}$ because of atypical absence seizures. A magnetic resonance imaging was normal and the child's IQ was estimated to be 100 despite some developmental and speech delay. An EEG showed a generalized slow spike and wave pattern and the patient was felt to suffer from Lennox-Gastaut syndrome. Rapid deterioration occurred after the age of four, and between the ages of four and six, she lost the ability to speak, walk, sit, and feed herself. Electron microscopy of white cells showed some nondiagnostic cytoplasmic vacuoles, and a rectal biopsy was negative. A skin biopsy done at the age of six revealed GROD.

Subject 20, a patient of Roberta Pagan of Seattle, Washington, developed normally until the age of 5 when visual problems were noted. Difficulties in school were noted at age 7 and he was diagnosed with a learning disability at age 10 . At age 15 , he is blind and requires assistance with walking, but enjoys listening to music, telling jokes, and meeting with friends. Two younger siblings are normal.

Preparation of crude lysates from EBV-transformed lymphoblasts. EBV-transformed lymphoblasts were maintained in suspension culture in RPMI 1640 medium containing $10 \%$ fetal bovine serum, $100 \mathrm{U} / \mathrm{ml}$ penicillin, $100 \mu \mathrm{g} / \mathrm{ml}$ streptomycin, and $0.25 \mu \mathrm{g} / \mathrm{ml}$ of amphotericin B. Aliquots $\left(10 \mathrm{ml}, 5 \times 10^{7}\right.$ cells $)$ were harvested by centrifugation, washed twice with ice-cold phosphate-buffered saline, and resuspended in $200 \mu \mathrm{l}$ of buffer containing $50 \mathrm{mM}$ Tris- $\mathrm{HCl}, \mathrm{pH}$ $7.4,150 \mathrm{mM} \mathrm{NaCl}, 2 \mathrm{mM}$ EDTA, $1 \mu \mathrm{g} / \mathrm{ml}$ of pepstatin, and $1 \mu \mathrm{g} / \mathrm{ml}$ of leupeptin. The cells were sonicated for two pulses of $6 \mathrm{~s}$ each at a setting of three using a Branson probe sonifier on ice. The homogenate was centrifuged at $100,000 \mathrm{~g}$ for $1 \mathrm{~h}$ at $4^{\circ} \mathrm{C}$. The clear supernatant was removed and the protein concentration determined using the Micro DC protein assay (Bio-Rad Laboratories, Hercules, CA).

PPT assay and immunoblotting. PPT activity was determined in crude soluble extracts of EBV-transformed lymphoblasts, essentially as described previously (19), with the exception that the extracts were incubated with $2 \mathrm{mM}$ phenylmethanesulfonyl fluoride at $37^{\circ} \mathrm{C}$ for 40 min to reduce nonspecific thioesterase activity just before assay. As- says were performed for $90 \mathrm{~min}$ at $37^{\circ} \mathrm{C}$ and terminated by the addition of $500 \mu \mathrm{l}$ of cold ethanol/ether $(2: 1, \mathrm{vol} / \mathrm{vol})$. Immunoblotting was performed using anti-human PPT antibodies raised in rabbits against purified recombinant human PPT produced in the insect cell baculovirus system as previously described (20).

Genomic DNA isolation. White blood cells were obtained from whole blood withdrawn in the presence of EDTA after red cell lysis. Total cellular DNA was isolated using a model 340A nucleic acid extractor (Applied Biosystems, Foster City, CA) and stored in a buffer containing $10 \mathrm{mM}$ Tris- $\mathrm{HCl}, \mathrm{pH} 8.0$, and $1 \mathrm{mM}$ EDTA.

PCR amplifications. Individual exons or portions of exons were amplified using PCR and thermostable DNA polymerases. The locations and sequences of the oligonucleotide primer pairs are given in Table III. PCR reactions were performed in $20 \mu \mathrm{l}$ reactions containing $20 \mathrm{ng}$ of genomic DNA, primer $(1 \mu \mathrm{M}), 0.2 \mathrm{mM}$ of dATP, dGTP, and dTTP, $0.02 \mathrm{mM}$ of dCTP, $0.05 \mu \mathrm{l}$ of $\left[{ }^{32} \mathrm{P}\right] \mathrm{dCTP}(\sim 3,000 \mathrm{mCi} /$ $\mathrm{mmol}$ ), $1 \mathrm{U}$ of Taq DNA polymerase, $10 \mathrm{mM}$ Tris- $\mathrm{HCl}, \mathrm{pH} 8.3,50$ $\mathrm{mM} \mathrm{KCl}$, and $1.5 \mathrm{mM} \mathrm{MgCl}$. Exons were amplified using a thermocycler program of 35 cycles of $30 \mathrm{~s}$ at $94^{\circ} \mathrm{C}, 30 \mathrm{~s}$ at the annealing temperature indicated in Table III, and $30 \mathrm{~s}$ at $72^{\circ} \mathrm{C}\left(5 \mathrm{~min}\right.$ at $72^{\circ} \mathrm{C}$ at cycle 35).

Single-stranded conformational polymorphism (SSCP) analysis. Conformation-dependent DNA polymorphisms were detected using polyacrylamide gels essentially as described by Orita et al. (21). Neutral polyacrylamide gels containing $7 \%$ acrylamide-bisacrylamide (29:1), $2 \times$ TBE (22), $0.056 \%$ (wt/vol) ammonium persulfate, and $0.001 \%(\mathrm{vol} / \mathrm{vol}) \mathrm{N}, \mathrm{N}, \mathrm{N}^{\prime}, \mathrm{N}^{\prime}$,-tetramethylethylenediamine were used in the presence and absence of $10 \%$ glycerol. Radiolabeled PCR products $(5 \mu \mathrm{l})$ corresponding to each exon (or portion thereof) were added to $15 \mu \mathrm{l}$ of formamide-loading buffer ( $95 \%$ (vol/vol) formamide, $20 \mathrm{mM}$ EDTA, $0.05 \%$ (wt/vol) each of bromophenol blue and xylene cyanol), incubated at $100^{\circ} \mathrm{C}$ for $5 \mathrm{~min}$, and cooled on ice. Aliquots $(5 \mu \mathrm{l})$ were electrophoresed at $280 \mathrm{~V}$ for $16 \mathrm{~h}$ at room temperature or for $420 \mathrm{~V}$ for $16 \mathrm{~h}$ (glycerol-containing gels). A nondenatured sample $(1 \mu \mathrm{l})$ of the original amplification reaction was diluted into 5 $\mu l$ of sucrose buffer (22) and loaded into an adjacent lane to determine the position of migration of the double-stranded exon DNA fragment. Some polymorphisms were detected only in $\mathrm{MDE}^{\circledR}$-containing gels (FMC, Inc., Rockport, ME), as indicated in the legend to Table III.

PCR from gels and sequencing. Radiolabeled bands were excised from SSCP gels, and used directly in $40 \mu \mathrm{l}$ PCR reactions under exactly the same conditions described above except that no radiolabeled nucleotide was added and the concentration of each deoxynucleotide was $0.2 \mathrm{mM}$. Amplification products were purified by electrophoresis in $1.5 \%$ agarose gels, purified on spin columns (Supelco, Bellefonte, PA), precipitated using sodium acetate and ethanol, and sequenced by automated dye terminator cycle sequencing.

\section{Results}

PPT deficiency in subjects with NCL. Table I shows the clinical diagnosis and electron microscopic findings for the patients entered into the study (60 subjects). We entered 32 subjects with 
Table II. Subjects with Neuronal Ceroid Lipofuscinosis due to Palmitoyl-Protein Thioesterase Deficiency

\begin{tabular}{|c|c|c|c|c|c|c|c|c|c|}
\hline \multirow[b]{2}{*}{ Ref. no. } & \multirow{2}{*}{$\begin{array}{l}\text { IBR-BD }^{\mathrm{a}} \\
\text { Registry no./ } \\
\text { Cell strain }\end{array}$} & \multirow[b]{2}{*}{ Ethnic group } & \multirow[b]{2}{*}{$\begin{array}{l}\text { Age of onset } \\
\text { and sex }\end{array}$} & \multirow{2}{*}{$\begin{array}{l}\text { Current age } \\
\text { or age } \\
\text { at death }\end{array}$} & \multirow[b]{2}{*}{$\begin{array}{c}\text { Presenting } \\
\text { symptom(s) }\end{array}$} & \multirow[b]{2}{*}{$\begin{array}{c}\mathrm{EM}^{\mathrm{b}} \\
\text { results }\end{array}$} & \multicolumn{3}{|c|}{ Molecular lesion } \\
\hline & & & & & & & Type & Location & Mutation \\
\hline \multicolumn{10}{|c|}{ Infantile NCL: } \\
\hline \multirow[t]{2}{*}{1} & $1465 /$ & Swedish/ & $3 \mathrm{mo}, \mathrm{M}$ & $7 \mathrm{yr}$ & Seizures & GROD & Missense & Exon 4 & A364T (R122W) \\
\hline & BD329 & Norwegian & & & & & Missense & Exon 6 & G541A $(\mathrm{V} 181 \mathrm{M})^{\mathrm{c}}$ \\
\hline \multirow[t]{2}{*}{2} & $1694 /$ & Penn Dutch & $6 \mathrm{mo}, \mathrm{M}$ & $2.5 \mathrm{yr}$ & Cognitive/Motor & GROD & Nonsense & Exon 5 & C451T (R151X) \\
\hline & $-^{\mathrm{d}}$ & Alsatian & & & & & Nonsense & Exon 5 & C490T (R164X) \\
\hline \multirow[t]{2}{*}{3} & $1474 /$ & Greek/Irish & $6 \mathrm{mo}, \mathrm{M}$ & $7.5 \mathrm{yr}$ & Seizures & GROD & Nonsense & Exon 1 & T29A (L10X) \\
\hline & BD445 & & & & & & Nonsense & Exon 1 & T29A (L10X) \\
\hline \multirow[t]{2}{*}{4} & $1547 /$ & German & $8 \mathrm{mo}, \mathrm{F}$ & $5 \mathrm{yr}$ & Cognitive & GROD & Nonsense & Exon 5 & C451T (R151X) \\
\hline & BD483 & & & & & & Nonsense & Exon 5 & $\mathrm{C} 451 \mathrm{~T}(\mathrm{R} 151 \mathrm{X})^{\mathrm{e}}$ \\
\hline \multirow[t]{2}{*}{5} & -1 & German/Eng/ & $8 \mathrm{mo}, \mathrm{M}$ & $7 \mathrm{yr}^{\mathrm{g}}$ & Motor & GROD & Nonsense & Exon 5 & C451T (R151X) \\
\hline & $95-52^{\mathrm{f}}$ & Polish & & & & & Nonsense & Exon 5 & $\mathrm{C} 451 \mathrm{~T}(\mathrm{R} 151 \mathrm{X})^{\mathrm{e}}$ \\
\hline \multirow[t]{2}{*}{6} & 1019/ & Scot/Irish/Eng/ & $8 \mathrm{mo}, \mathrm{F}$ & $6.5 \mathrm{yr}$ & Seizures & GROD & Deletion & Exon 4 & del 398T \\
\hline & BD437 & Germ/Swedish & & & & & Nonsense & Exon 5 & C451T (R151X) \\
\hline \multirow[t]{2}{*}{7} & $1461 /$ & Swedish/Dutch & $12 \mathrm{mo}, \mathrm{F}$ & $13 \mathrm{yr}$ & Motor & GROD & Nonsense & Exon 5 & C451T (R151X) \\
\hline & BD475 & & & & & & Nonsense & Exon 5 & C451T (R151X) \\
\hline \multirow[t]{2}{*}{8} & $1676 /$ & Germ/Welsh/ & $12 \mathrm{mo}, \mathrm{M}$ & $2.5 \mathrm{yr}$ & Seizures/cognitive & GROD & Nonsense & Exon 5 & C451T (R151X) \\
\hline & UT17-01 & NatAm/Ital & & & & & Nonsense & Exon 5 & $\mathrm{C} 451 \mathrm{~T}(\mathrm{R} 151 \mathrm{X})^{\mathrm{e}}$ \\
\hline \multirow[t]{2}{*}{9} & -1 & Germ/Welsh/ & $12 \mathrm{mo}, \mathrm{F}$ & $2.5 \mathrm{yr}$ & Cognitive/motor & GROD & Nonsense & Exon 5 & C451T (R151X) \\
\hline & UT8-01 & Cherok/Ital & & & & & Nonsense & Exon 5 & C451T (R151X) \\
\hline 10 & $1196 /$ & Swedish/ & $12 \mathrm{mo}, \mathrm{M}$ & $4 \mathrm{yr}^{\mathrm{g}}$ & Vision & GROD & Missense & Exon 2 & G125A (G42E) \\
\hline & BD192 & Norwegian & & & & & Missense & Exon 4 & A364T (R122W) \\
\hline 11 & $1652 /$ & Ir/Welsh/Eng/ & $12 \mathrm{mo}, \mathrm{M}$ & $4 \mathrm{yr}$ & Cognitive/motor & GROD & Missense & Exon 1 & T117A $(\mathrm{H} 39 \mathrm{Q})^{\mathrm{c}}$ \\
\hline & UT11-01 & Germ/Norweg & & & & & Nonsense & Exon 5 & C451T (R151X) \\
\hline 12 & $1725 /$ & Welsh/Eng/ & $12 \mathrm{mo}, \mathrm{M}$ & $2.5 \mathrm{yr}$ & Cognitive/motor & GROD & Nonsense & Exon 5 & C451T (R151X) \\
\hline & UT14-01 & German/Dutch & & & & & Splice site & $\begin{array}{l}\text { Intron } 7 / \\
\text { Exon } 8\end{array}$ & $\mathrm{~T}(\text { IVS7, }-2)^{\mathrm{c}}$ \\
\hline 13 & $1674 /$ & Irish/English/ & n.a., $M$ & n.a. & No information & GROD & Missense & Exon 4 & A364T (R122W) \\
\hline & BD442 & Swedish & & & & & Missense & Exon 6 & G550A (E184K) \\
\hline 14 & $1601 /$ & Norw/Can/ & $18 \mathrm{mo}, \mathrm{F}$ & $7.5 \mathrm{yr}$ & Seizures/cognitive & GROD & Nonsense & Exon 1 & T29A (L10X) \\
\hline & UT18-01 & Cherokee & & & & & Missense & Exon 3 & T325G (Y109D) \\
\hline$\underline{\text { Late inf }}$ & antile NCL: & & & & & & & & \\
\hline $15^{\mathrm{h}}$ & $1031 /$ & Scottish/Irish/ & $18 \mathrm{mo}, \mathrm{F}$ & $14 \mathrm{yr}$ & Seizures/cognitive & GROD & Nonsense & Exon 5 & C451T (R151X) \\
\hline & BD076 & Germ/English & & & & & Nonsense & Exon 5 & C451T (R151X) \\
\hline 16 & $1112 /$ & German/Irish & $18 \mathrm{mo}, \mathrm{M}$ & $13 \mathrm{yr}$ & Cognitive & GROD/ & Nonsense & Exon 5 & C451T (R151X) \\
\hline & BD052 & & & & & $\mathrm{CV}$ & Missense & Exon 6 & G541A $(\mathrm{V} 181 \mathrm{M})^{\mathrm{c}}$ \\
\hline $17^{\mathrm{i}}$ & $1576 /$ & Arab/ & $18 \mathrm{mo}, \mathrm{M}$ & $7 \mathrm{yr}$ & Vision/cognitive & GROD & Nonsense & Exon 5 & C490T (R164X) \\
\hline & C10949 & Moroccan & & & & & - & - & - \\
\hline $18^{\mathrm{k}}$ & $1005 /$ & Scottish/ & $3.5 \mathrm{yr}, \mathrm{M}$ & $13 \mathrm{yr}$ & Cognitive/motor & GROD & Missense & Exon 1 & G3A (M1I) \\
\hline & BD004 & German/Irish & & & & & Missense & Exon 3 & $\mathrm{~T} 325 \mathrm{G}(\mathrm{Y} 109 \mathrm{D})$ \\
\hline 19 & $1639 /$ & English & $3.5 \mathrm{yr}, \mathrm{F}$ & $12 \mathrm{yr}$ & Seizures & GROD & Missense & Exon 5 & C529G (Q177E) \\
\hline & UT2-01 & & & & & & Nonsense & Exon 9 & G888A (W296X) \\
\hline Juven & NCL: & & & & & & & & \\
\hline 20 & $1400 /$ & German/ & $5 \mathrm{yr}, \mathrm{M}$ & $15 \mathrm{yr}$ & Vision & GROD & Missense & Exon 1 & G3A (M1I) \\
\hline & BD282 & Native Amer & & & & & Missense & Exon 8 & T739 C (Y247H) \\
\hline 21 & $1523 /$ & German & $5 \mathrm{yr}, \mathrm{F}$ & $19 \mathrm{yr}$ & Vision & GROD & Nonsense & Exon 5 & C451T (R151X) \\
\hline & C10316 & & & & & & Missense & Exon 8 & $\mathrm{G} 749 \mathrm{~T}(\mathrm{G} 250 \mathrm{~V})^{\mathrm{c}}$ \\
\hline 22 & $1162 /$ & French Can/ & $5 \mathrm{yr}, \mathrm{F}$ & $20 \mathrm{yr}$ & Vision & GROD/ & Missense & Exon 2 & $\mathrm{~A} 223 \mathrm{C}(\mathrm{T} 75 \mathrm{P})$ \\
\hline & $\mathrm{C} 7297$ & Irish & & & & $\mathrm{CV} / \mathrm{FP}$ & Nonsense & Exon 5 & C451T (R151X) \\
\hline 23 & $1428 /$ & Nor/Germ/ & $6 \mathrm{yr}, \mathrm{M}$ & $17 \mathrm{yr}$ & Cognitive & GROD/ & Missense & Exon 2 & $\mathrm{~A} 223 \mathrm{C}(\mathrm{T} 75 \mathrm{P})$ \\
\hline & BD309 & Irish/English & & & & $\mathrm{CV}$ & Nonsense & Exon 5 & C451T (R151X) \\
\hline 24 & $1553 /$ & Scot/Ir/Eng/ & $6 \mathrm{yr}, \mathrm{F}$ & $16 \mathrm{yr}$ & Vision & GROD & Missense & Exon 2 & $\mathrm{~A} 223 \mathrm{C}(\mathrm{T} 75 \mathrm{P})$ \\
\hline & C11029 & Fre/FreCan & & & & & Nonsense & Exon 5 & C451T (R151X) \\
\hline
\end{tabular}

(Continued) 


\begin{tabular}{|c|c|c|c|c|c|c|c|c|c|}
\hline \multirow[b]{2}{*}{ Ref. no. } & \multirow{2}{*}{$\begin{array}{l}\text { IBR-BD }^{\mathrm{a}} \\
\text { Registry no./ } \\
\text { Cell strain }\end{array}$} & \multirow[b]{2}{*}{ Ethnic group } & \multirow[b]{2}{*}{$\begin{array}{l}\text { Age of onset } \\
\text { and sex }\end{array}$} & \multirow{2}{*}{$\begin{array}{l}\text { Current age } \\
\text { or age } \\
\text { at death }\end{array}$} & \multirow[b]{2}{*}{$\begin{array}{c}\text { Presenting } \\
\text { symptom(s) }\end{array}$} & \multirow[b]{2}{*}{$\begin{array}{c}\mathrm{EM}^{\mathrm{b}} \\
\text { results }\end{array}$} & \multicolumn{3}{|c|}{ Molecular lesion } \\
\hline & & & & & & & Type & Location & Mutation \\
\hline \multirow[t]{2}{*}{25} & $1210 /$ & Scot/Irish/ & $7 \mathrm{yr}, \mathrm{M}$ & $17 \mathrm{yr}$ & Vision & GROD/ & Missense & Exon 2 & A223C (T75P) \\
\hline & BD037 & Germ/Hung & & & & $\mathrm{CV} / \mathrm{FP}$ & Nonsense & Exon 5 & C451T (R151X) \\
\hline \multirow[t]{2}{*}{26} & $1321 /$ & German/ & $7 \mathrm{yr}, \mathrm{M}$ & $24 \mathrm{yr}^{\mathrm{g}}$ & Vision & GROD/ & Missense & Exon 2 & $\mathrm{~A} 223 \mathrm{C}(\mathrm{T} 75 \mathrm{P})$ \\
\hline & $11993^{\mathrm{d}}$ & Irish & & & & $\mathrm{CV} / \mathrm{FP}$ & Missense & Exon 6 & G541A (V181M)c \\
\hline \multirow[t]{2}{*}{27} & $1419 /$ & n.a. & $7 \mathrm{yr}, \mathrm{F}$ & $19 \mathrm{yr}$ & Vision/cognitive & GROD/ & Missense & Exon 2 & A223C (T75P) \\
\hline & $16025^{\mathrm{d}}$ & & & & & $\mathrm{CV} / \mathrm{FP}$ & Deletion & Exon 7 & del 644A \\
\hline \multirow[t]{2}{*}{$28^{1}$} & $1418 /$ & English/ & $7.5 \mathrm{yr}, \mathrm{F}$ & $18 \mathrm{yr}$ & Seizures & GROD & Missense & Exon 3 & $\mathrm{~A} 236 \mathrm{G}(\mathrm{D} 79 \mathrm{G})^{\mathrm{m}}$ \\
\hline & 20105 & Hispanic & & & & & Nonsense & Exon 5 & C451T (R151X) \\
\hline \multirow[t]{2}{*}{$29^{n}$} & $1357 /$ & Scottish & $7 \mathrm{yr}, \mathrm{F}$ & $26 \mathrm{yr}$ & Cognitive & GROD & Missense & Exon 2 & $\mathrm{~A} 223 \mathrm{C}(\mathrm{T} 75 \mathrm{P})$ \\
\hline & UT7-01 & & & & & & Missense & Exon 2 & A223C (T75P) \\
\hline
\end{tabular}

$a$, Institute for Basic Research Batten Disease Registry (Staten Island, NY). $b$, Electron microscopy. $G R O D=$ granular osmiophilic deposits; $C V=$ curvilinear profiles; $F P=$ fingerprint profiles. $c$, SSCP detected in MDE-containing gels only. $d$, PPT assay/immunoblot not performed. $e$, homozygosity inferred from SSCP and Southern analysis. $f$, fibroblast line. $g$, deceased. $h$, Subject 3 of (17). $i$, Subject 5 of (17). $j$, Coding region normal by DNA sequencing. $k$, Subject 1 of (17). $l$, Subject 208-II-3 of (18). $m$, no SSCP abnormality. $n$, Subject 56-II-1 of (18). n.a., not available.

GROD histology (23 with "pure" GROD and 9 with GROD mixed with curvilinear and/or fingerprint profiles), 16 classical LINCL subjects with curvilinear histology, and 12 subjects referred because of an initial clinical suspicion of INCL who had nondiagnostic histopathology. We found an excellent correlation between the presence of GROD and the absence of PPT activity (Table I). Cell lines were available for 29 of the 32 GROD subjects, and 26 of these showed PPT levels that were $<0.2 \mathrm{pmoles} / \mathrm{min} / \mathrm{mg}$ of protein (normal range, 1-3 pmoles/ $\mathrm{min} / \mathrm{mg}$ of protein). Three additional subjects, for whom cell lines were not available (indicated in Table II) are classified as PPT-deficient based on the finding of mutations in the PPT coding region. Overall, PPT deficiency was found in 23 of 23 NCL probands who showed pure GROD, and six out of nine subjects with GROD mixed with curvilinear or fingerprint inclusions. (The remaining three subjects, all juvenile presentations, had normal PPT activity and no mutations in PPT-coding regions identified by SSCP. One of these was subsequently found to have a mutation in the $C L N 3$ gene [K. Wisniewski, unpublished data]. The basis for the neurodegeneration in the remaining two cases is unknown).

We also assayed lymphoblasts from 16 classical LINCL subjects for PPT activity (Table I, third row) and an additional 12 cases in which there was a clinical suspicion of INCL by a referring neurologist (Table I, fourth row). These 12 subjects had nondiagnostic histology (Table I, fourth row). All of these subjects with neurological syndromes, but without GROD, had normal PPT activity (data not shown).

PPT-deficient subjects. Table II summarizes the important clinical, pathological, and genetic features of the 29 unrelated PPT-deficient subjects identified in this study. Subjects were found to be distributed among the infantile, late infantile, and juvenile groups (Table II), with ages of onset ranging from as early as 3 mo to as late as $7 \mathrm{yr}$. (The latest onset among all affected relatives was $9 \mathrm{yr}$, in a sibling of Subject 29). About half $(14 / 29$, or $48 \%)$ carried the diagnosis of INCL, and were clinically similar to the Finnish INCL subjects described previously (13). 5 out of the 29 (17\%) carried the diagnosis of LINCL. Two of these (Subjects 15 and 17) presented at 18 mo (within the defined range of onset for infantile cases, which is up to $24 \mathrm{mo}$ ), but carried the late infantile diagnosis because each had an older sibling that had presented at 24 mo of age. Subject 16 presented at 18 mo of age, but carried the diagnosis of "late infantile" because of the finding of curvilinear bodies (in addition to GROD) on electron microscopy and because he demonstrated a protracted clinical course. Subject 19 presented at the age of $3.5 \mathrm{yr}$ and was felt to be an unusual classical late infantile patient because seizures dominated the clinical picture. 10 out of the 29 cases $(34 \%$ ) carried the diagnosis of JNCL. These cases were clinically indistinguishable from JNCL with CLN3 mutations, with visual failure as the presenting symptom in most cases. These results, taken together, reveal the remarkable degree of clinical heterogeneity in terms of age of onset among PPT-deficient subjects in our population.

PPT mutations. Table II lists the molecular lesions in the coding regions of the PPT gene in the 29 subjects analyzed, and Fig. 2 shows these mutations in relation to their location in the PPT gene. We identified 56 of 58 mutated alleles by SSCP analysis, and one further allele by sequencing of each exon. In one subject (Subject 17) only one mutated allele was detected, despite exhaustive analysis, including sequencing of all exons and Southern analysis. (PPT deficiency in this subject is most likely due to a mutation that maps outside of the exons and immediate flanking regions examined here). Taken together, 19 different mutations were found (including 14 not previously reported) and these consisted of 12 amino acid substitutions, four nonsense codons, two instances of single base-pair deletions, and one splice-site mutation.

The most common mutation (a nonsense mutation) accounted for $\sim 40 \%$ of PPT alleles in affected individuals (Fig. 2). This mutation was $C$ to $T$ transition at position 451 of the human PPT cDNA (relative to the translation start site) and occurred at the site of a $\mathrm{CpG}$ dinucleotide, presumably as a consequence of methylation-mediated deamination of cytosine (23). Of the 19 mutations described in the current paper, three others (C490T, G541A, and G550A) also occurred at $\mathrm{CpG}$ dinucleotides sites. The next most common mutation 
Table III. Oligonucleotides Used for PCR Amplification of the PPT Gene

\begin{tabular}{|c|c|c|c|c|}
\hline Amplification target & Oligonucleotide & Location & Sequence $5^{\prime}$ to $3^{\prime}$ & Annealing temperature \\
\hline \multirow[t]{2}{*}{ Exon 1 (5' portion) } & SH 521 & 5'-UTR, Exon 1 & CTGGGCATCCGTTCGGATG & $58^{\circ} \mathrm{C}$ \\
\hline & 4809 & Exon 1 & AGATGCTGCAGCGCCCGAGA & \\
\hline \multirow[t]{2}{*}{ Exon 1 ( $3^{\prime}$ portion $)$} & SH 485 & Exon 1 & TGTGGCTCTTGGCTGTGGCTCTCC & $55^{\circ} \mathrm{C}$ \\
\hline & SH 486 & Intron 1 & АСССТTTTAAATTTCTСAСTСACT & \\
\hline \multirow[t]{2}{*}{ Exon 2} & SH 489 & Intron 1 & AGTTTCCATCATTGTGTTTTGTTG & $55^{\circ} \mathrm{C}$ \\
\hline & SH 490 & Intron 2 & AACAGCTGTGAAGCCCCTTAC & \\
\hline \multirow[t]{2}{*}{ Exon 3 (5' portion) } & SH 491 & Intron 2 & GTCCCATCCTCTCACTTCT & $55^{\circ} \mathrm{C}$ \\
\hline & SH 492 & Exon 3 & ATCCCATAGCATTGTAGC & \\
\hline \multirow[t]{2}{*}{ Exon 3 ( $3^{\prime}$ portion) } & SH 493 & Exon 3 & GTCAATTCCCAAGTAACAACAGT & $58^{\circ} \mathrm{C}$ \\
\hline & SH 494 & Intron 3 & GGTACAATATAACAAAAAGGAACG & \\
\hline \multirow[t]{2}{*}{ Exon 4} & SH 495 & Intron 3 & ATACATTTCCATCTGACAGTC & $55^{\circ} \mathrm{C}$ \\
\hline & SH 519 & Intron 4 & GTGGGTTAGAATACAGAAAAA & \\
\hline \multirow[t]{2}{*}{ Exon 5} & SH 520 & Intron 4 & GAAGGAGTGGATATTGTCAT & $58^{\circ} \mathrm{C}$ \\
\hline & SH 498 & Intron 5 & GTAATCTTTTCAGCTAGCCATACA & \\
\hline \multirow[t]{2}{*}{ Exon $6\left(5^{\prime}\right.$ portion $)$} & SH 573 & Intron 5 & TGGGCGTACTGACTGACCTG & $55^{\circ} \mathrm{C}$ \\
\hline & SH 570 & Exon 6 & GTGCTTACCCGCTCCTGATTTAT & \\
\hline \multirow[t]{2}{*}{ Exon 6 ( $3^{\prime}$ portion $)$} & SLM 8 & Intron 5/Exon 6 & CCTACAGCCTCGTGCAAACC & $60-50^{\circ} \mathrm{C}$ ("touchdown")* \\
\hline & SH 404 & Intron 6 & TCTGCCCAGGACAGTTTGGG & \\
\hline \multirow[t]{2}{*}{ Exon 7} & SH 501 & Intron 6 & GGTGTTGCTGGCCTTTCTTTCA & $60^{\circ} \mathrm{C}$ \\
\hline & SH 502 & Intron 7 & GCATGTGGCCTAAGTAGTGTCTCA & \\
\hline \multirow[t]{2}{*}{ Exon 8} & SH 503 & Intron 7 & GстTстTTсстTTGстTст & $55-45^{\circ} \mathrm{C}$ ("touchdown")* \\
\hline & SH 504 & Intron 8 & AACCTCCCAAGATAGACTCC & \\
\hline \multirow[t]{2}{*}{ Exon $9\left(5^{\prime}\right.$ portion $)$} & SH 505 & Intron 8 & TTTTAATTAATTATGGCCTTTCCT & $55-45^{\circ} \mathrm{C}$ ("touchdown")* \\
\hline & SH 506 & Exon 9 & TGGGCATAAAACCATTCTTCAGAC & \\
\hline \multirow[t]{2}{*}{ Exon 9 ( $3^{\prime}$ portion $)$} & SH 507 & Exon 9 & CTGGGGCTAAAGGAAATGGA & $55^{\circ} \mathrm{C}$ \\
\hline & SH 508 & $3^{\prime}$-UTR, Exon 9 & TCCCTGAGCTCTATTGTGAACTAT & \\
\hline
\end{tabular}

*For each of 10 cycles, the annealing temperature was decreased in one degree increments from the upper to lower temperature, and held constant at the lower temperature for an additional 25 cycles.

(eight alleles) was an $\mathrm{A}$ to $\mathrm{C}$ transversion at position 223, which causes a substitution of proline for threonine at amino acid position 75 . This mutation was previously reported in Scottish juvenile-onset cases with GROD (18). The Finnish mutation, A364T (R122W), was observed in three instances. None of these reported Finnish descent, but all three reported Swedish ethnicity. (This may be significant, because the Swedish-speaking population is Finland's largest ethnic minority [24]). A G541A (V181M) mutation was observed in three alleles, and the remaining mutations were rare. Two previously reported mutations, T656A (L219Q) (18) and A163T (K55X) (2) were not observed.

Two nucleotide polymorphisms (G-83A, 6/200 alleles, and C401T (I134T), 4/200 alleles) were identified in affected subjects and/or their family members. Both of these polymorphisms were found associated with wild-type alleles in obligate heterozygotes. No polymorphisms, including the two described above, were identified through the SSCP analysis of 30 normal control subjects.

PPT mutations and clinical expression. Fig. 3 shows the approximate age of onset of four clinical manifestations of NCL (seizures, visual deterioration, cognitive decline, and motor disturbances) for subjects bearing mutations in the PPT gene. Each symbol represents one proband of an unrelated family, and 27 families are represented. The most striking finding is the broad range of ages at which symptoms first appeared.
This striking heterogeneity stands in sharp contrast to Finnish patients (essentially all R122W homozygotes), who uniformly present before $2 \mathrm{yr}$ of age. In Fig. 3, yellow circles represent subjects bearing two nonsense or a nonsense and a frameshift mutation. These would be expected to be among the most severely affected of subjects, and as seen in Fig. 3, all of these nonsense/frameshift subjects presented before the age of $2 \mathrm{yr}$, with universal early deficits in cognitive and motor function, and more variable onset of seizures and apparent visual deficits.

The vast majority of the remaining subjects were compound heterozygotes, and these subjects varied a great deal in age of onset (Fig. 3). However, certain mutations were clearly associated with a later age of onset and protracted course. The T75P "Scottish" mutation, observed in both the homozygous state (solid red triangles) and heterozygous state (red half-triangles) was seen in seven subjects, all of whom presented at 5 yr or later with visual problems. These subjects were clinically indistinguishable from juvenile NCL (CLN3) patients. Other alleles seen in juvenile-onset cases were D79G (purple half-circles), Y247H (black half-triangles), and G250V (black halfrectangles). Late infantile presentations were associated with two missense mutations (Q177E, blue half-triangles, and Y109D, inverted blue half-triangles). Because only one or two affected families bearing these four mutations were identified, their predictive value remains to be determined. 

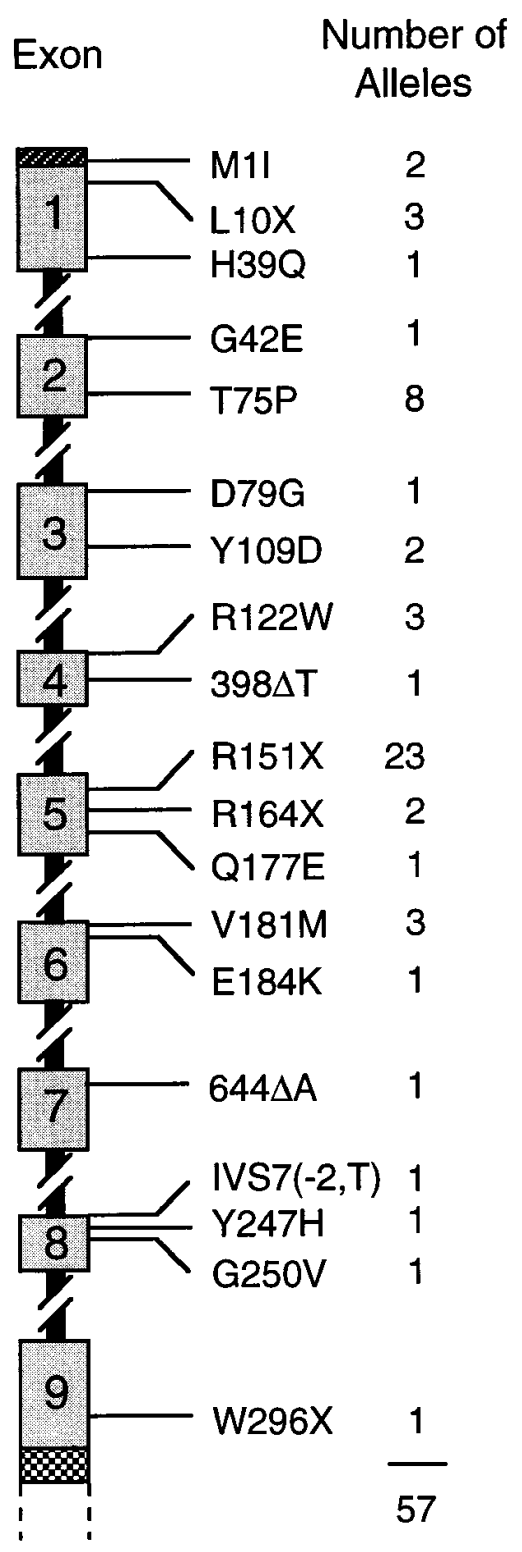

Figure 2. Location of mutations in the PPT gene in 29 subjects with NCL. The number of times a given allele was observed is shown on the right. A total of 57 mutation-bearing alleles was identified. In one subject, the exon sequences on one PPT allele were normal.
Many of the mutations occurred at the location of invariant residues (G42E, Y109D, R122W, Q177E, Y247H, and G250V) (Fig. 4). The T75P substitution (which occurred in seven juvenile-onset families), is located at a position that is not well conserved; in fact, the Arabidopsis enzyme appears to have dispensed with eight residues in this region, including the threonine at position 75 . Family 29 in our series contains two affected sisters that are both homozygous for the T75P allele, and they have had a very mild clinical course, with ages of onset of 7 and $9 \mathrm{yr}$. (These sisters are still living, but are institutionalized, having reached the unusual ages of 26 and $29 \mathrm{yr}$ ).

To begin to directly assess the effect of these amino acid substitutions on PPT enzymatic activity, we compared enzyme activity in lymphoblasts from normal subjects, obligate heterozygotes, and patients with infantile, late infantile, and juvenile-onset disease (Fig. 5). Normal lymphoblasts showed values for PPT enzyme activity in the range of 1.9-2.7 pmoles/ $\mathrm{min} / \mathrm{mg}$ in this experiment, and the obligate heterozygotes showed values between 0.5 and $2 \mathrm{pmoles} / \mathrm{min} / \mathrm{mg}$. All of the NCL subjects with PPT mutations showed $<0.2$ pmoles $/ \mathrm{min} /$ $\mathrm{mg}$ of protein, a value approximately equal to the background of the assay. The assay was not sufficiently sensitive to distinguish differences between infantile and juvenile-onset subjects. However, residual enzyme activity in the range of $2-4 \%$ of normal was associated with several alleles (T75P and $\mathrm{Y} 247 \mathrm{H}$ ) in studies of recombinant mutant enzymes expressed in 293 and COS cells (data not shown).

Missense mutations may influence enzyme function, or they may change enzyme protein levels through effects on enzyme synthesis or stability. To begin to assess the effect of various mutations on PPT protein levels, crude soluble extracts were prepared from lymphoblasts from 26 subjects, and subjected to SDS-PAGE and immunoblotting using antibodies raised against human recombinant PPT. Unexpectedly, severely reduced levels of immunoreactive enzyme protein were consistently observed in all 26 cell lines (data not shown). A more detailed examination of the synthesis and degradation of each of these mutant enzymes will be needed to permit conclusions to be drawn regarding the impact of individual mutations on protein expression levels.

\section{Discussion}

In the current paper, we demonstrate that PPT deficiency in the U.S. is a clinically and molecularly heterogeneous disease. Nonsense mutations that inactivate both alleles of the PPT gene (CLN1) result in INCL. These subjects resemble the Finnish CLN1 patients in clinical expression. However, a number of missense mutations in the PPT gene result in a more slowly progressive neurodegeneration that is clinically indistinguishable from classical late-infantile and juvenile-onset NCL, diseases more frequently associated with mutations in the $C L N 2$ and $C L N 3$ genes. Furthermore, we show here that these milder forms of PPT deficiency are distinguished from CLN2 and $C L N 3$ diseases by the appearance of the storage material by electron microscopy, as the late-onset PPT-deficient subjects show inclusion bodies (GROD) that are also characteristic of infantile cases (although in the late-onset PPT-deficient patients, GROD mixed with curvilinear and/or fingerprint profiles are often seen). Only $50 \%$ of the PPT-deficient subjects presented in the infantile age range $(0-2 \mathrm{yr})$, whereas $17 \%$ were classified as late-infantile (2-4 yr), and $33 \%$ were ju- 


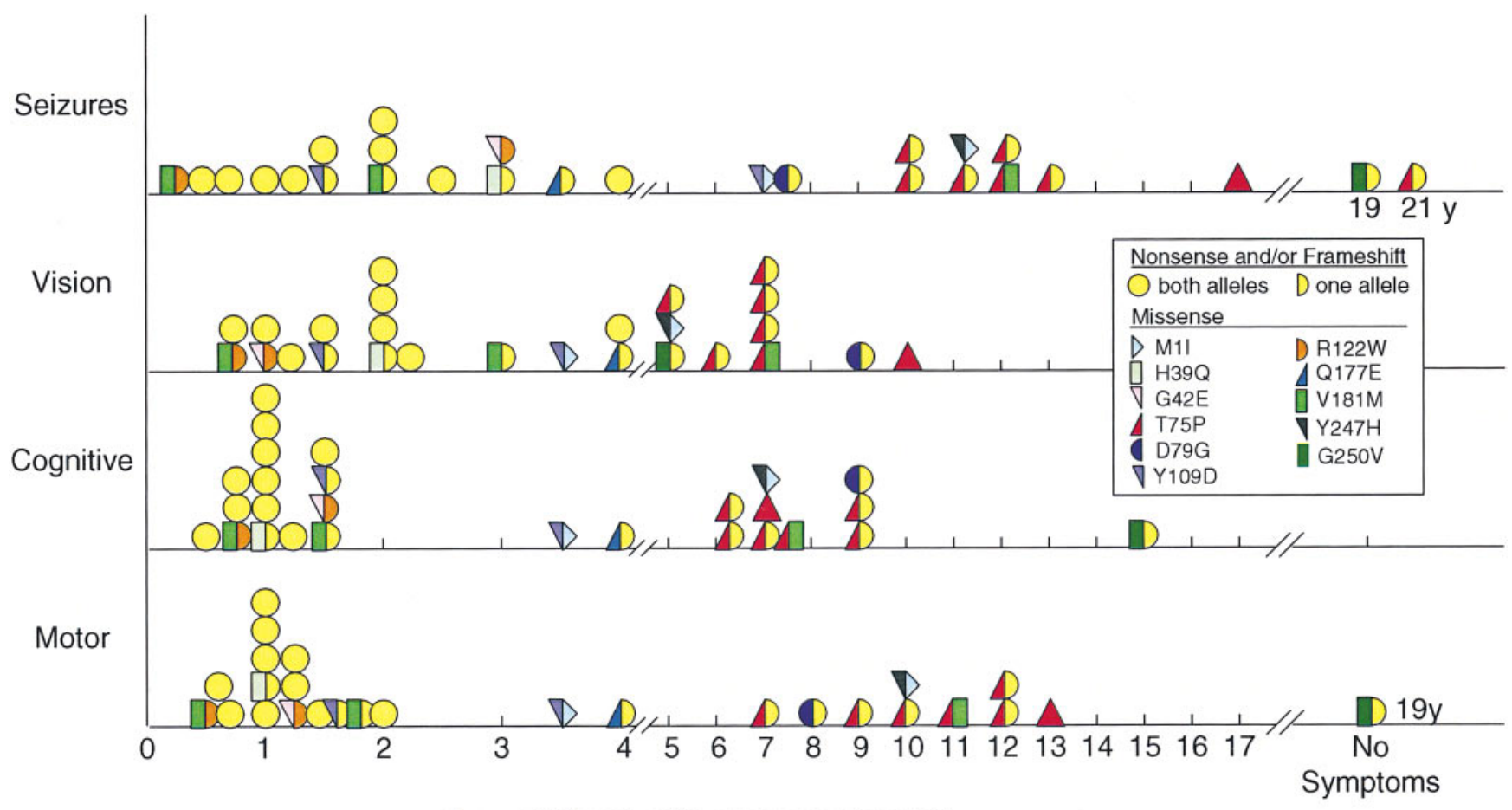

Age of Onset of Symptoms (years)

Figure 3. Age of onset of seizures, visual, cognitive, and motor deterioration in PPT-deficient subjects. Probands from 27 independent families are shown. Each symbol represents a subject, and the left and right halves of each symbol represent PPT alleles. The mutation associated with each allele is indicated by color and shape as given in the legend. The scale from 0 to $4 \mathrm{yr}$ of age was expanded for clarity. Subjects not exhibiting a given symptom are listed to the extreme right, and the subject's current age is given under the symbol.

venile ( $5 \mathrm{yr}$ or more). Therefore, the classification of the NCLs by age of onset is beginning to break down as a molecular definition of these diseases emerges.

The current paper greatly expands the spectrum of PPT gene mutations, for a total of 21 to date. 19 different mutations were observed in our U.S. cohort, 14 of which have not been described previously. One nonsense mutation, R151X, accounted for $40 \%$ of disease alleles. This mutation would be expected to be very severe, and the clinical data is consistent with this interpretation, as R151X homozygotes demonstrated rapidly progressive deterioration. As expected, we demonstrated that the C451T (R151X) mutation results in undetectable levels of PPT protein. Premature termination codons frequently result in low levels of mRNA as well, by an unknown cellular mechanism that links mRNA processing or transport to translation (27). This mechanism is likely to be contributing to the molecular defect in these subjects, because this allele could not be amplified from cDNA generated from these subjects by reverse transcriptase (18, and our own unpublished observations). (On a practical note, given the frequency of the C451T allele in the U.S. population, analysis of genomic DNA, as was done here, rather than analysis of cDNA, may be the preferred method for determining mutations in PPT-deficient subjects for this reason). A second mutation, T75P, accounted for $13 \%$ of the alleles and each of these subjects was a juvenile-onset NCL patient with predominantly GROD histology. The remaining PPT mutations were infrequently observed and scattered throughout all nine exons of the PPT gene. Three mutations, D79G, Y247H, and G250V, were found only in ju- venile-onset subjects. We did not observe two other known mutations, a Belgian mutation L219Q (18), or a British mutation K55X (2), in our U.S. subjects.

Interestingly, the T75P mutation (accounting for most of the JNCL subjects) occurred on a nonconserved residue, and we were able to detect a low amount (2-4\%) of residual activity associated with an expressed protein bearing this mutation. We conclude from these observations that even low levels of enzyme activity may partially ameliorate the NCL phenotype seen in the most severely affected patients. Therefore, one might be more optimistic about enzyme replacement therapy with the knowledge that high levels of enzyme activity are probably not required.

The finding that all of our subjects showed decreased levels of immunoreactive PPT protein in lymphoblasts was unexpected. This is not a previously well documented finding among lysosomal storage diseases, and our results may be biased by the rather large number of subjects carrying nonsense mutations. However, our observation supports the approach taken by Lobel and colleagues (5), who recently successfully identified the enyzme defective in late-infantile NCL using a method that relies on detecting the absence of the defective protein. It will be interesting to see whether there is also a preponderance of cross-reactive material-negative mutations in late infantile NCL subjects. Perhaps mutant lysosomal enzyme instability will be found to be a general feature of the neuronal ceroid lipofuscinoses.

In the course of the above studies, we also identified a small subset of juvenile-onset NCL subjects with granular his- 

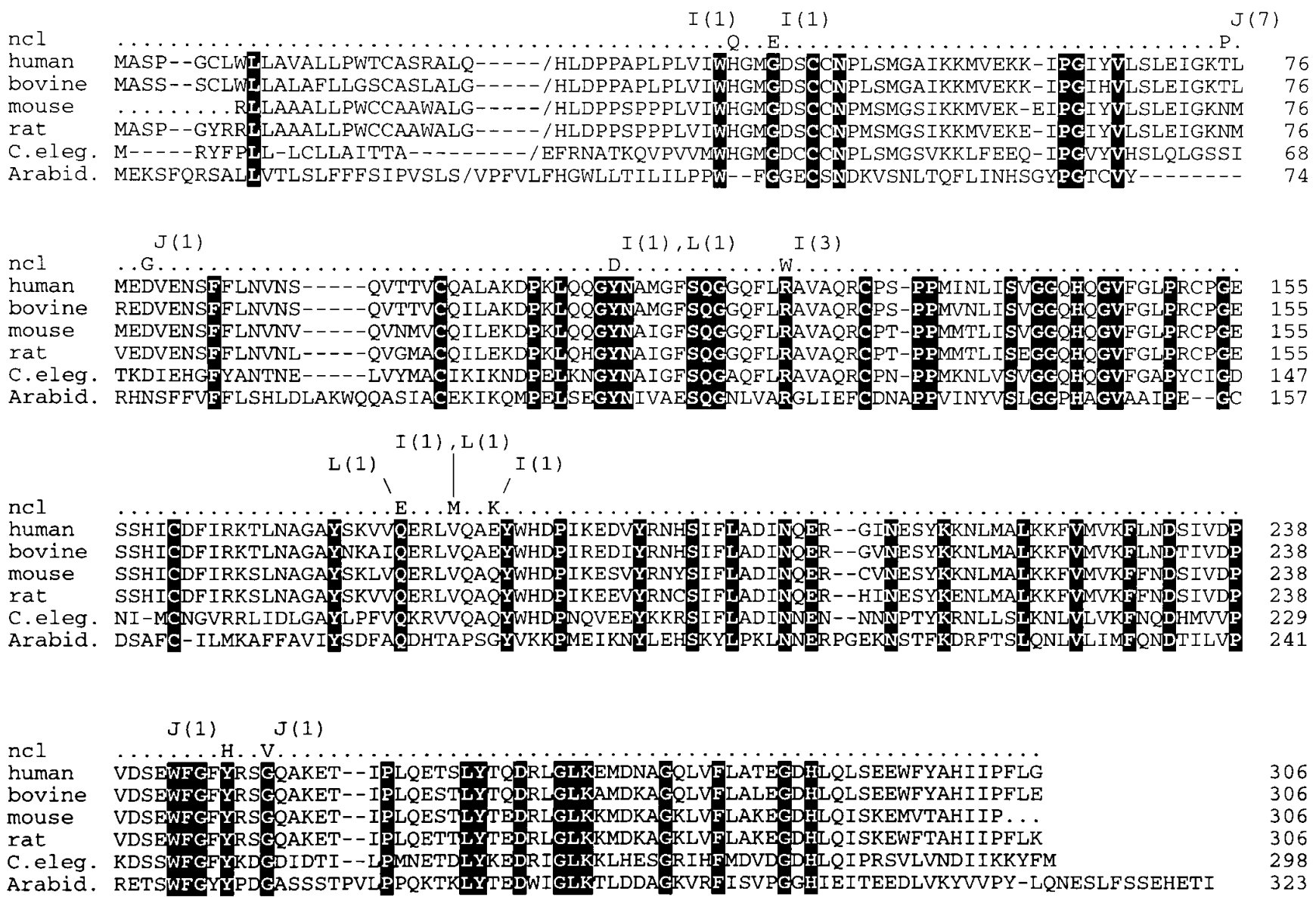

Figure 4. Location of selected missense mutations in relation to invariant amino acid residues of PPT. In the top line, amino acid changes found in NCL subjects that were co-inherited with nonsense mutations are given. The clinical phenotype ( $I$, infantile, $L$, late infantile, and $J$, juvenile) is indicated as a superscript above the mutated residue, and the number of subjects observed with that mutation is indicated in parentheses. Invariant residues are shaded in black. The human, bovine, and rat PPT cDNA sequences have been published previously $(3,26)$. The mouse PPT amino acid sequences were derived from the expressed sequence-tagged database using the BLAST algorithm of the NCBI, and are incomplete at the $5^{\prime}$ and $3^{\prime}$ ends. The $C$. elegans and Arabidopsis coding sequences were derived directly from genomic sequences in the Genome Database (GenBank/EMBL/DDBJ accession numbers U50313 and Z97343, respectively), using the program Genefinder of the NCBI, with the exception that amino acids 192-232 of the Arabidopsis sequence were derived by visual inspection of the genomic sequence.

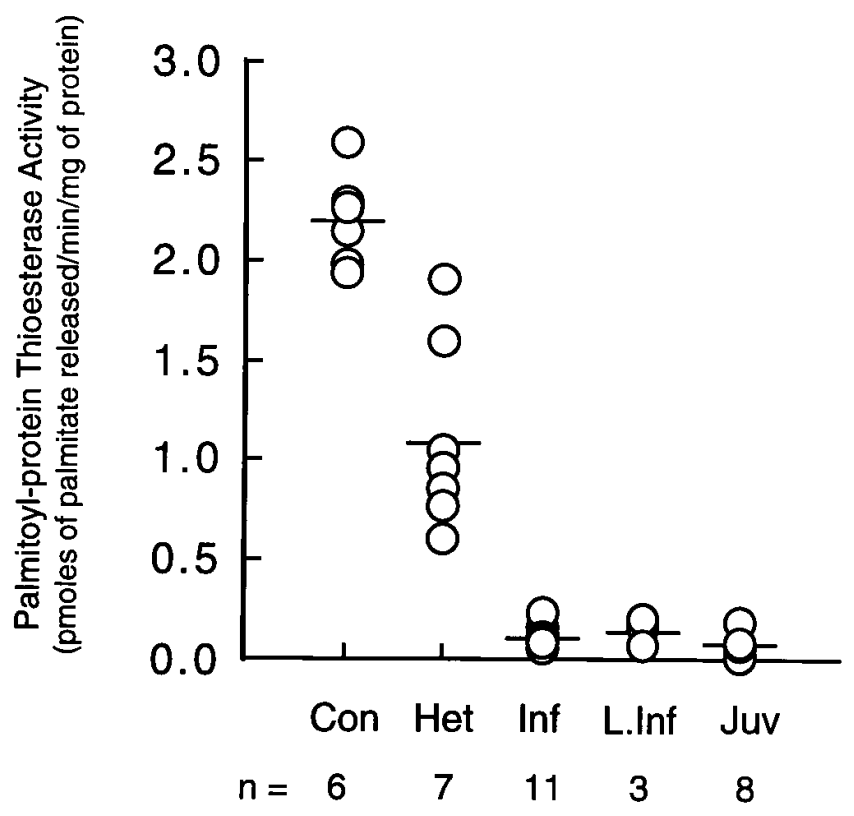

tology typical of PPT deficiency, but in whom normal enzyme levels could be demonstrated. We hypothesize that these subjects have a defect in another, perhaps novel, lysosomal enzyme. The method of Lobel and colleagues (5) may be useful for the identification of the putative defective lysosomal enzyme in these subjects, especially if the technique can be developed for the analysis of tissues outside the central nervous system.

\section{Acknowledgments}

We wish to thank the families, the Batten Disease Support and Research Association (BDSRA), and the following physicians who

Figure 5. PPT activity in crude soluble extracts of lymphoblasts derived from control (Con), Het (obligate NCL heterozygotes), INCL (Inf), LINCL ( L. Inf.), and JNCL (Juv) subjects. Values (mean \pm SD) for PPT activity were $2.2 \pm 0.24,1.2 \pm 0.05,0.10 \pm 0.04,0.14 \pm 0.05$, and $0.07 \pm 0.05$ pmoles of palmitate released from $\left[{ }^{3} \mathrm{H}\right]$ palmitate-labeled $\mathrm{H}-\mathrm{Ras} / \mathrm{min} / \mathrm{mg}$ of soluble cell protein, respectively. The number of observations is listed below each category. 
cared for these patients and/or referred patients for this study: Todd Barron, David Bick, Galen Breningstol, Lawrence Berstein, Daryl Crisp, William Dobyns, Stephen Glass, Claudia Gibson, Patricia Hartledge, Mark Laney, Paul Levisohn, Rose-Mary Boustany, Teresa Hadro, Marianne Larson, Terry Lerner, John McDonald, Holmes Morton, Sakkubai Naidu, Marvin Natowicz, Roberta Pagan, Michel Philippart, Ronald Shiak, Harvey Singer, Liza Squires, Robert Steiner, Terry Watkin, Richard Weleber, and Leon Wolf. We thank Edith Dockter, coordinator of the Batten Disease Registry at the Institute for Basic Research, and Lance Johnston of the BDRSA, for making this work possible. We thank Victor Stastny for meticulous cell culture and Lynda Doolittle for DNA sequencing.

This study was supported by a grant from the National Institutes of Health (NS 36867 to S. Hofmann) and a fellowship from Amgen (C.H.R. Becerra). The Indiana University Batten Disease Cell Bank (samples labeled BD) is supported by NS 30171 and funds from the BDSRA and the Children's Brain Diseases Foundation.

\section{References}

1. Goebel, H.H. 1995. The neuronal ceroid-lipofuscinoses. J. Child Neurol. 10:424-437.

2. Vesa, J., E. Hellsten, L.A. Verkruyse, L.A. Camp, J. Rapola, P. Santavuori, S.L. Hofmann, and L. Peltonen. 1995. Mutations in the palmitoyl protein thioesterase gene causing infantile neuronal ceroid lipofuscinosis. Nature. 376: $584-587$.

3. Schriner, J.E., W. Yi, and S.L. Hofmann. 1996. cDNA and genomic cloning of human palmitoyl-protein thioesterase (PPT), the enzyme defective in infantile neuronal ceroid lipofuscinosis. Genomics. 34:317-322.

4. Sharp, J.D., R.B. Wheeler, B.D. Lake, M. Savukoski, I.E. Jarvela, L. Peltonen, R.M. Gardiner, and R.E. Williams. 1997. Loci for classical and a variant late infantile neuronal ceroid lipofuscinosis map to chromosomes 11p15 and 15q21-23. Hum. Mol. Genet. 6:591-595.

5. Sleat, D.E., R.J. Donnelly, H. Lackland, C.-G. Liu, I. Sohar, R.K. Pullarkat, and P. Lobel. 1997. Association of mutations in a lysosomal protein with classical late-infantile neuronal ceroid lipofuscinosis. Science. 277:1802-1805.

6. Anonymous. 1995. Isolation of a novel gene underlying Batten disease, CLN3. The International Batten Disease Consortium. Cell. 82:949-957.

7. Kufs, H. 1925. Uber eine spatform der amaurotishcen idiotie and ihre heredofamiliaren grundlagen. Z. Ges. Neurol. Psychiatr. 95:169-188.

8. Savukoski, M. M. Kestila, R. Williams, I. Jarvela, J. Sharp, J. Harris, P. Santavuori, M. Gardiner, and L. Peltonen. 1994. Defined chromosomal assignment of CLN5 demonstrates that at least four genetic loci are involved in the pathogenesis of human ceroid lipofuscinoses. Am. J. Hum. Genet. 55:695-701.

9. Dyken, P.R., and K.E. Wisniewski. 1995. Classification of the neuronal ceroid-lipofuscinoses: expansion of the atypical forms. Am. J. Med. Genet. 57: $150-154$

10. Wisniewski, K.E., E. Kida, O.F. Patxot, and F. Connell. 1992. Variability in the clinical and pathological findings in the neuronal ceroid lipofuscinoses: review of data and observations. Am. J. Med. Genet. 42.525-532.
11. Hofmann, S.L., L.A. Lee, J.-Y. Lu, and L.A. Verkruyse. 1997. Palmitoyl-protein thioesterase and the molecular pathogenesis of infantile neuronal ceroid lipofuscinosis. Neuropediatrics. 28:27-30.

12. Lu, J.-Y., L.A. Verkruyse, and S.L. Hofmann. 1996. Lipid thioesters derived from acylated proteins accumulate in infantile neuronal ceroid lipofuscinosis: correction of the defect in lymphoblasts by recombinant palmitoyl-protein thioesterase. Proc. Natl. Acad. Sci. USA. 93:10046-10050.

13. Santavuori, P., M. Haltia, and J. Rapola. 1974. Infantile type of so-called neuronal ceroid-lipofuscinosis. Dev. Med. Child Neurol. 16:644-653.

14. Jansky, J. 1908. Dosud nepopsany pripad familiarni amauroticke idiotie komplilovane s hypoplasii mozeckovou. Sbom Lek. 13:165-196.

15. Bielschowsky, M. 1913. Uber spat-infantile familiare amaurotische idiotie mit kleinhimsymptomen. Dtsch. Z. Nervenheilk. 50:7-29.

16. Batten, F.E. 1903. Cerebral degeneration with symmetrical changes in the maculae in two members of a family. Trans. Ophthalmol. Soc. UK. 23:386390

17. Wisniewski, K.E., F. Connell, W. Kaczmarski, A. Kaczmarski, A. Siakotos, C.R. Becerra, and S.L. Hofmann. 1998. Palmitoyl-protein thioesterase deficiency in a novel granular variant of late infantile neuronal ceroid lipofuscinosis. Pediatr. Neurol. 18:119-123.

18. Mitchison, H.M., S.L. Hofmann, C.H.R. Becerra, P.B. Munroe, B.D. Lake, Y.J. Crow, J.B.P. Stephenson, R. Williams, I.L. Hofman, J.-J. Martin, et al. 1998. Mutations in the palmitoyl-protein thioesterase gene (PPT;CLN1) causing juvenile neuronal ceroid lipofuscinosis with granular osmiophilic deposits. Hum. Mol. Genet. 7:291-297.

19. Camp, L.A., and S.L. Hofmann. 1993. Purification and properties of a palmitoyl-protein thioesterase that cleaves palmitate from H-Ras. J. Biol. Chem. 268:22566-22574.

20. Verkruyse, L.A., M.R. Natowicz, and S.L. Hofmann. 1997. Palmitoylprotein thioesterase deficiency in fibroblasts of individuals with infantile neuronal ceroid lipofuscinosis and I-cell disease. Biochim. Biophys. Acta. 1361:1-5

21. Orita, M., Y. Suzuki, T. Sekiya, and K. Hayashi. 1989. Rapid and sensitive detection of point mutations and DNA polymorphisms using the polymerase chain reaction. Genomics. 5:874-879.

22. Sambrook, J., E.F. Fritsch, and T. Maniatis. 1989. Molecular Cloning: A Laboratory Manual. Cold Spring Harbor Laboratory Press, Cold Spring Harbor, NY.

23. Cooper, D.N., M. Krawczak, and S.E. Antonarakis. 1995. The nature and mechanisms of human gene mutation. In The Metabolic and Molecular Bases of Inherited Disease. Vol. 1. C.R. Scriver, A.L. Beaudet, W.S. Sly, and D. Valle, editors. McGraw-Hill, New York. 261-263.

24. Nevanlinna, H.R. 1972. The Finnish population structure: a genetic and genealogical study. Hereditas. 71:195-236.

25. Hellsten, E., J. Vesa, V.M. Olkkonen, A. Jalanko, and L. Peltonen. 1996. Human palmitoyl protein thioesterase: evidence for lysosomal targeting of the enzyme and disturbed cellular processing in infantile neuronal ceroid lipofuscinosis. EMBO (Eur. Mol. Biol. Oragn.) J. 15:5240-5245.

26. Camp, L.A., L.A. Verkruyse, S.J. Afendis, C.A. Slaughter, and S.L. Hofmann. 1994. Molecular cloning and expression of palmitoyl-protein thioesterase. J. Biol. Chem. 269:23212-23219.

27. Cooper, D.N., M. Krawczak, and S.E. Antonarakis. 1995. The nature and mechanisms of human gene mutation. In The Metabolic and Molecula Bases of Inherited Disease. Vol. 1. C.R. Scriver, A.L. Beaudet, W.S. Sly, and D. Valle, editors. McGraw-Hill, New York. 269-270. 